\title{
Occupation-related physical activities in osteoarthritis of the knee in
}

\section{female}

\author{
Mohammed Emran, Syed Mozaffar Ahmed, Md. Israt Hasan and Ali Emran
}

\author{
Article Info \\ Department of Physical Medicine and \\ Rehabilitation, Faculty of Medicine, \\ Bangabandhu Sheikh Mujib Medical \\ University, Shahbag, Dhaka, Bangladesh \\ For Correspondence: \\ Mohammed Emran \\ emran.pmr@gmail.com \\ Received: \\ Accepted: \\ Available Online \\ 14 March 2019 \\ 26 April 2019 \\ 1 July 2019 \\ ISSN: 2224-7750 (Online) \\ 2074-2908 (Print) \\ DOI: 10.3329/bsmmuj.v12i2.41230
}

Keywords: Female; Knee; Occupation Osteoarthritis; Physical activity

Cite this article:

Emran M, Ahmed SM, Hasan MI, Emran A. Occupation-related physical activities in osteoarthritis of the knee in female. Bangabandhu Sheikh Mujib Med Univ J. 2019; 12: 84-87.

\section{Copyright:}

The copyright of this article is retained by the author(s) [Atribution CC-By 4.0]

Available at:

www.banglajol.info

A Journal of Bangabandhu Sheikh Mujib Medical University, Dhaka, Bangladesh
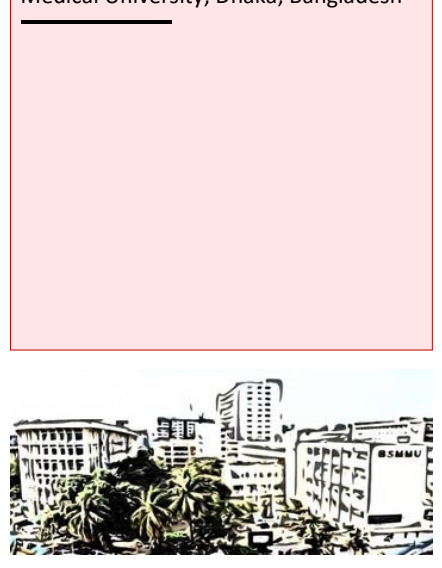

\section{Abstract}

The aim of this study was to determine the role of occupation-related physical activities in the osteoarthritis of the knee. The study was conducted on 87 female patients from September 2016 to August 2017. The same number of healthy females of the same age group were included as a control. Data was collected using a structured interviewer-administered questionnaire, enquiring about demographic data and details of risk factors. There were statistically significant $(\mathrm{p}<0.05)$ changes in the occupation-related physical activities like sustained knee bending, climbing stairs (>10 flights/day), kneeling (>30 $\mathrm{min} /$ day), squatting (>30 min/day), in patients when compared to the control group. However, there were no significant changes in other occupation-related physical activities. Obese (BMI $\geq 30 \mathrm{~kg} / \mathrm{m}^{2}$ ) patients were found $29.9 \%$ in the patient and $17.2 \%$ in the control group. Patients with a positive family history of osteoarthritis of the knee were $13.8 \%$ in the case group and $3.4 \%$ in the control group. The difference was statistically significant $(p<0.05)$ between the two groups. In conclusion, occupation-related physical activities like sustained knee bending, climbing stairs, kneeling and squatting had a significant association with osteoarthritis of the knee in the female.

\section{Introduction}

Osteoarthritis of the knee is the most common form of joint disease and among the top 10 causes of disability worldwide. 1 It's a degenerative joint disease, occurring primarily in older individuals, characterized by erosion of the articular cartilage, hypertrophy of bone at the margins, subchondral sclerosis, and a range of biochemical and morphological alterations of the synovial membrane and joint capsule.?

Multiple factors are responsible in the etiology of osteoarthritis of the knee including generalized constitutional factors for example- age, sex, obesity, heredity, reproductive variables and local adverse mechanical factors for example- trauma, occupational and recreational usage, alignment. 3,4 In a family-based study, the heritability of osteoarthritis ranges between $43 \%$ at the knee to $60 \%$ and $65 \%$ at the hip and hand, respectively. .5

It is important to identify the risk factors for the development of strategies for primary and secondary prevention of osteoarthritis of the knee. $\underline{6}$

The occupational activities that causing osteoarthritis of the knee by frequent exposure to several biomechanical stressors are heavy physical workload, bending of the knee, regular stair climbing, kneeling, squatting, sitting, standing $\geq 2$ hours per day, walking $\geq 3 \mathrm{~km} /$ day, jumping and vibration.

Activity modification is a very important component in the management of the osteoarthritis of the knee.12

Obesity is significantly associated with osteoarthritis of the knee compared to less BMI. $\underline{13}$ The effect of obesity in osteoarthritis of the knee is malalignment. $\underline{14}$ Obese individuals have 1.5 to 2 times the risk of developing osteoarthritis of the knee.15 Fowler-Brown et al (2015) found that a $5 \mathrm{~kg} / \mathrm{m}^{2}$ increase in BMI was associated with a $32 \%$ increase in the probability of osteoarthritis and leptin contributed approximately half of the total effect of obesity on osteoarthritis of the knee. $\underline{16}$

Until now a few studies of the association between factors related to osteoarthritis of the knee have been carried out in a representative sample. Therefore, it is clear that there is a need to determine the factors related to osteoarthritis of the knee of people.

The present study was designed to examine the relationship between occupation-related physical activities and body mass index with the osteoarthritis of the knee in the female. 


\section{Materials and Methods}

This case-control study was conducted from September 2016 to August 2017. In total 174 female participants (age range: 40-70 years) were divided into two groups: 87 patients with osteoarthritis of the knee as the case and 87 were without osteoarthritis of the knee as the control. Data were collected using a structured interviewer-administered questionnaire, enquiring about demographic data and details of risk factors. There was a minimum physical, psychological, social and legal risk. Heights and weights were measured to calculate body mass index.

\section{Statistical analysis}

Statistical analysis was carried out by using the Statistical Package for Social Sciences version 23.0 for Windows (SPSS Inc., Chicago, Illinois, USA). The quantitative observations were indicated by frequencies and percentages. Chi-Squared test was used to analyze the categorical variables, shown with cross tabulation. The $p$ value of $<0.05$ was considered statistically significant.

\section{Results}

The mean age of both groups was 57 years. Among the 87 patients, 23 were doing activities with sustained knee bending, 18 with climbing stairs $>10$ flights/day, 17 with kneeling $>30 \mathrm{~min} /$ day, 11 with squatting $>30 \mathrm{~min} /$ day whereas, in control group, the values were $9,8,6$, and 2 respectively. The $p$ value was found significant $(\mathrm{p}<0.05)$. The other occupation-related physical activities were not statistically significant $(p>0.05)$ between the two groups (Table I).

The number of patients with obesity (BMI $\geq 30 \mathrm{~kg} /$ $\mathrm{m}^{2}$ ) was 26 and in the control group, it was 15 which was statistically significant $(p<0.05)$ between the two groups.

\section{Table I}

Occupation-related physical activities of the study population

\begin{tabular}{|lccc|}
\hline Occupation-related physical activities & $\begin{array}{c}\text { Case } \\
(\mathrm{n}=87)\end{array}$ & $\begin{array}{c}\text { Control } \\
(\mathrm{n}=87)\end{array}$ & $\mathrm{p}$ value \\
\hline Squatting (>30 min/ day) & 11 & 2 & $0.009 \mathrm{~s}$ \\
Kneeling (>30 min/ day) & 17 & 6 & $0.014^{\mathrm{s}}$ \\
Climbing stairs (>10 flights/ day) & 18 & 8 & $0.033^{\mathrm{s}}$ \\
Walking ( $>2$ miles/ day) & 27 & 24 & $0.617^{\mathrm{ns}}$ \\
Standing (>2 hours/day) & 31 & 26 & $0.419 \mathrm{~ns}$ \\
Sitting (>2 hours/day) & 26 & 21 & $0.393^{\mathrm{ns}}$ \\
Sustained knee bending & 23 & 9 & $0.006^{\mathrm{s}}$ \\
s= significant, ns= not significant & & & \\
\hline
\end{tabular}

There were 12 patients with a positive family history of osteoarthritis of the knee and the value was 3 in the control group, which was significant $(\mathrm{p}<0.05)$.

\section{Discussion}

This study reveals sustained knee bending, climbing stairs, kneeling, squatting were important in the development of osteoarthritis of the knee in the female. However, other occupation-related physical activities were not statistically significant $(p>0.05)$ between the two groups. Obesity and family history of osteoarthritis of the knee were significantly higher in the case group than the control group.

This study agrees with Haq and Davatchi (2011) where squatting and cycling were modifiable risk factors for osteoarthritis of the knee. 17

In a previous study, sustained knee bending was found responsible for osteoarthritis of the knee, in which 8 participants were in the case group and 11 were in the control group. $\underline{18}$

The other study observed there was an association between the stair climbing and osteoarthritis of the knee and there is 2 times more possible chance to develop osteoarthritis of the knee due to stair climbing regularly. $\underline{19}$

It is found in a study that occupational knee bending is a positive risk factor for the development of osteoarthritis of the knee. The odds of getting osteoarthritis with increased occupational knee bending were significantly higher than for those who had no knee bending. The odds ratio varied from 1.2 to 6.9 for different types of knee bending. $\underline{20}$

Haq and Davatchi (2011) explained overweight as a risk factor for osteoarthritis of the knee $\underline{17}$ but this study revealed that obesity a significant one and agree with Shakoor et al. (2009)느 and Dieppe (1995) 22 Excess body weight is a risk for developing osteoarthritis of the knee.23 Obesity has been identified as a significant risk factor for osteoarthritis of the knee in Britain, $\underline{24}$ Sweden, $\underline{25}$ and Japan. $\underline{26}$ A study in Morocco found that the mean BMI was $30.5 \pm 4.4$ $\mathrm{kg} / \mathrm{m}^{2}$ in the case group and $27.6 \pm 3.8$ in control group. The difference was statistically significant $(p<0.05)$ between the two groups. 27 These findings support the result of this study. Some studies showed overweight as significant for osteoarthritis of the knee and there is 2.25 times more possible chance to occur osteoarthritis of the knee due to overweight.18, 19 Other studies also observed that $70.6 \%$ of patients had BMI $\geq 25.0 \mathrm{~kg} / \mathrm{m}^{2}$ in men group and $47.7 \%$ in woman group. .28 Mean BMI was high $29.4 \pm 7.8$ in osteoarthritis cases. $\underline{29}$

According to review heritability for the 
osteoarthritis of the knee ranges between $43 \% . \underline{5}$ Some studies found an association between the positive family history and the osteoarthritis of the knee.18 Patil et al. (2012) reported $19.4 \%$ of patients had a positive family history in the female group. .30 These are in favor of this present study.

\section{Conclusion}

Sustained knee bending, climbing stairs, kneeling, squatting, obesity, positive family history are risk factors for osteoarthritis of the knee.

\section{Conflict of interest}

There is no conflict of interest.

\section{Ethical Issue}

A well-informed, voluntary, signed written consent was taken in an understandable local language from the study subjects before enrollment after convincing them that privacy, anonymity, and confidentiality of data information identifying any patient were maintained strictly. Each patient enjoyed every right to participate or refuse or even withdraw from the study at any point in time. The protocol was approved by the Institutional Review Board of Bangabandhu Sheikh Mujib Medical University (BSMMU/2017/441).

\section{References}

1. Hafez AR, Alenazi AM, Kachanathu SJ, Alroumi AM, Mohamed ES. Knee osteoarthritis: A review of literature. Phys Med Rehabil Int. 2014; 1: 8.

2. Paul E, Cesare DI, Dominik R, Haudenschild. Pathogenesis of Osteoarthritis. In: Kelly's Textbook of rheumatology. Firestein G, Budd R, Gabriel SE, McInnes LB, O'Dell J (eds). 9th ed. Philadelphia Elsevier Saunders, 2013, p 1617.

3. Felson DT, Lawrence RC, Dieppe PA, Hirsch $\mathrm{R}$, Helmick CG, Jordan JM, Kington RS, Lane NE, Nevitt MC, Zhang Y, Sowers M, McAlindon T, Spector TD, Poole AR, Yanovski SZ, Ateshian G, Sharma L, Buckwalter JA, Brandt KD, Fries JF. Osteoarthritis: New insights. Part 1: The disease and its risk factors. Ann Intern Med. 2000; 133: 635 46.

4. Cooper C, Snow S, McAlindon TE, Kellingray S, Stuart B, Coggon D, Dieppe DA. Risk factors for the incidence and progression of radiographic knee osteoarthritis. Arthritis Rheum. 2000; 43: 995-1000.

5. Ralston SH, McInnes IB. Rheumatology and bone disease. In: Walke B, Colledge NR, Ralston S, Penman L (eds). Davidsons Principle and practice of medicine. 22nd ed. China, Churchill Livingstone,
2014: 1081

6. Haq SA, Davatchi F, Dahaghin S, Islam N, Ghose A, Darmawan J, Chopra A, Yu ZQ, Dans LF, Rasker JJ. Development of a questionnaire for identification of the risk factors for osteoarthritis of the knees in developing countries: A pilot study in Iran and Bangladesh. An ILAR-COPCORD phase III study. Int J Rheum Dis. 2010; 13: 203-14.

7. Sandmark H, Hogstedt C, Vingard E. Primary osteoarthrosis of the knee in men and women as a result of lifelong physical load from work. Scand J Work Environ Health. 2000; 26: 20-5.

8. Felson DT, Hannan MT, Naimark A, Berkeley J, Gordon G, Wilson PW, Anderson J. Occupational physical demands, knee bending, and knee osteoarthritis: Results from the Framingham Study. J Rheumatol. 1991; 18: 1587-92.

9. O'Reilly SC, Muir KR, Doherty M. Occupation and knee pain: A community study. Osteoarthritis Cartilage. 2000; 8: 78-81.

10. Teichtahl AJ, Wluka AE, Wang Y, Urquhart DM, Hanna FS, Berry PA, Jones G, Cicuttini FM Occupational activity is associated with knee cartilage morphology in females. Maturitas 2010; 66: 72-76.

11. Muraki S, Akune T, Oka H, Mabuchi A, En-yo Y, Yoshida M, Saika A, Nakamura K, Kawaguchi $\mathrm{H}$, Yoshimura N. Association of occupational activity with radiographic knee osteoarthritis and lumbar spondylosis in elderly patients of population-based cohorts: A large-scale population -based study. Arthritis Rheum. 2009; 61: 779-86.

12. Shakoor MA, Taslim MA, Hossain MS. Effects of activity modification on the patients with osteoarthritis of the knee. Bangladesh Med Res Counc Bull. 2007; 33: 55-59.

13. Tondare D, Kumbhar S, Kishore KJ, Khadervali N. Study of association of age and BMI with knee osteoarthritis among females in age group of 40 to 60 years in urban population of Kadapa town. Int J Community Med Public Health. 2017; 4: 1515-18.

14. Sharma MK, Swami HM, Bhatia V, Verma A, Bhatia SPS, Kaur G. An epidemiological study of correlates of osteoarthritis in geriatric population of UT Chandigarh. Indian J Community Med. 2007; 32: $77-78$

15. Felson DT, Anderson JJ, Naimark A, Walker AM, Meenan RF. Obesity and knee osteoarthritis: The Framingham Study. Ann Intern Med. 1988; 109: 1824.

16. Fowler-Brown A, Kim DH, Shi L, Marcantonio E, Wee CC, Shmerling RH, Leveille S. The mediating effect of leptin on the relationship between body weight and knee osteoarthritis in older adults. Arthritis Rheumatol. 2015; 67: 169-75.

17. Haq SA, Davatchi F. Osteoarthritis of the knees in the COPCORD world. Int J Rheum Dis. 2011; 14 
122-29.

18. Aftab A, Siddiqui FA, Babur MN, Memon AR. Risk factors in the development of knee osteoarthritis: A case-control study. Int J Rehabil Sci. 2015; 4: 7-10.

19. Elahee A. Risk factors of developing knee osteoarthritis. J Bangladesh Health Professions Inst. 2012; 10: 1-53.

20. Cooper C, McAlindon T, Coggon D, Egger P, Dieppe $\mathrm{P}$. Occupational activity and osteoarthritis of the knee. Ann Rheum Dis. 1994; 53: 90-3.

21. Shakoor MA, Taslim MA, Ahmed MS, Hasan SA. Clinical profile of patients with osteoarthritis of the knee: A study of 162 cases. IJPMR. 2009; 20: 44-47.

22. Dieppe PA. Clinical features and diagnostic problems in osteoarthritis. In: Practical rheumatology. Klipple JH, Dieppe PA (ed). London, Mosby, 1995, pp 141-56.

23. Hurley M. The clinical and cost-effectiveness of physiotherapy in the management of older people with common rheumatological conditions. Chartered Society of Physiotherapy. 2002, pp 221-30.

24. Coggon D, Croft P, Kellingray S, Barrett D, McLaren M, Cooper C. Occupational physical activities and osteoarthritis of the knee. Arthritis Rheum. 2000; 43: 1443-49.
25. Jarvholm B, Lewold S, Malchau H, Vingard E. Age, body weight, smoking habits and the risk of severe osteoarthritis in the hip and knee in men. Eur J Epidemiol. 2005; 20: 537-42.

26. Yoshimura N, Nishioka S, Kinoshita H, Hori N, Nishioka T, Ryujin M, Mantani Y, Miyake M, Coggon D, Cooper C. Risk factors for knee osteoarthritis in Japanese women: Heavy weight, previous joint injuries and occupational activities. J Rheumatol. 2004; 31: 157-62.

27. Mounach A, Nouijai A, Ghozlani I, Ghazi M, Achemlal L, Bezza A, El Maghraoui A. Risk factors for knee osteoarthritis in Morocco: A case-control study. Clin Rheumatol. 2008; 27: 323-26.

28. Rossignol M, Leclerc A, Allaert FA, Rozenberg S, Valat JP, Avouac B, Coste P, Litvak E, Hilliquin P. Primary osteoarthritis of hip, knee, and hand in relation to occupational exposure. Occup Environ Med. 2005; 62: 772-77.

29. Iqbal MN, Haidri FR, Motiani B, Mannan A. Frequency of factors associated with knee osteoarthritis. J Pakistan Med Assoc. 2011; 61: 786-89.

30. Patil PS, Dixit UR, Shettar CM. Risk factors of osteoarthritis knee: A cross-sectional study. IOSRJDMS. 2012; 2: 8-10. 